\title{
English Learning Management of Maritim Taruna in Seamanship Education and Training Center of Malahayati Aceh
}

\author{
Diah Vitaloka Hartati' ${ }^{1}$ Yusrizal $^{2}$, Bahrun $^{3}$. \\ ${ }^{1}$ BP2IP Malahayati Aceh, Indonesia. \\ ${ }^{2}$ Graduate School of Education, Syiah Kuala University, Indonesia \\ *Corresponding email: yusrizal_fkip@unsyiah.ac.id
}

Received: 09 October 2021

Accepted: 20 November 2021

Published: 29 November 2021

Abstract: This study aims to describe the planning, implementation and evaluation of Maritime English learning at BP2IP Malahayati. The technique of collecting data uses direct observation, in-depth interviews and documentation studies. Data analysis techniques through three stages, namely data reduction, data presentation and conclusion. The results of the study show that: (1) Planning for learning maritime English in BP2IP Malahayati consists of compiling syllabus in accordance with IMO Model Course 3.12 and compiling lesson plan (RPP) at the beginning of the semester; (2) The implementation of Maritime English learning at BP2IP Malahayati consists of initial activities, core activities delivered by learning materials and closing activities of the instructor giving assignments or quizzes to determine the extent to which students receive learning: (3) Evaluation of Maritime English Learning at BP2IP Malahayati carried out monitoring of students on 4 aspects, namely Listening, reading, speaking and writing. For the mid semester, midterms are given and at the end of the semester are given final semester examinations and practical exams.

Keywords: learning management, english, seamanship education and training center

Abstrak: Penelitian ini bertujuan untuk mendeskripsikan perencanaan, pelaksanaan dan evaluasi pembelajaran Bahasa Inggris Maritim di BP2IP Malahayati. Teknik pengumpulan data menggunakan observasi langsung, wawancara mendalam dan studi dokumentasi. Teknik analisis data melalui tiga tahap yaitu reduksi data, penyajian data dan penarikan kesimpulan. Hasil penelitian menunjukkan bahwa: (1) Perencanaan pembelajaran bahasa Inggris maritim di BP2IP Malahayati terdiri dari penyusunan silabus sesuai IMO Model Course 3.12 dan penyusunan rencana pembelajaran (RPP) di awal semester; (2) Pelaksanaan pembelajaran Bahasa Inggris Maritim di BP2IP Malahayati terdiri dari kegiatan awal, kegiatan inti yang disampaikan materi pembelajaran dan kegiatan penutup yaitu instruktur memberikan tugas atau kuis untuk mengetahui sejauh mana siswa menerima pembelajaran: (3) Evaluasi Bahasa Inggris Maritim Pembelajaran di BP2IP Malahayati melakukan monitoring siswa pada 4 aspek yaitu Listening, reading, speaking dan writing. Untuk tengah semester diberikan ujian tengah semester dan pada akhir semester diberikan ujian akhir semester dan ujian praktek.

Kata kunci: menejemen pembelajaran, bahasa inggris, pusat pendidikan dan pelatihan ilmu pelayaran.

\section{To cite this article:}

Hartati, D.V., Yusrizal, \& Bahrun. (2021). Malahayati Aceh Maritime English Learning Management of Cadets in Education and Navigation Training Center Malahayati Aceh. Jurnal Pendidikan Progresif, 11(3), 580-586. doi: 10.23960/jpp.v11.i3.2021009. 


\section{INTRODUCTION}

Efforts to improve the quality of education seem to never stop. Many reform agendas have been, are being, and will be implemented. Various innovative programs participated in enlivening education reform. Educational reform is the restructuring of education, namely improving the pattern of school relations with its environment and with the government, the pattern of development planning and the pattern of developing managerial, empowering teachers and restructuring learning models.

Quality education can produce qualified human resources as well. As mandated by the opening of the 1945 Constitution, the government is obliged to provide education to educate the nation's life. For this reason, all Indonesian citizens are required to demand education.

BP2IP Malahayati is an educational institution under the auspices of Minister of Transportation for Human Resource Development Transportation Center (BPSDM). BP2IP Malahayati has the main task of carrying out education and training in the field of shipping at the level of education and training at the primary and secondary levels in accordance with the standards and provisions of applicable laws and regulations. Reality in general BP2IP Malahayati Aceh has a tall and magnificent building.

In his education BP2IP Malahayati has several subjects. One of them is Maritime English lesson. English is one of the official languages in international organizations such as the United Nations and official languages in various countries. Therefore, English is used as one of subject in various educational institutions in Indonesia. One of the educational institutions that make English as the main language of learning is shipping education institutions. It can be seen from the efforts of the International Maritime Organization (IMO) in intensifying learning English, especially maritimeEnglish.
In accordance with a predetermined curriculum English Maritime has a high learning hours. Researchers were interested in conducting research at BP2IP Malahayati Aceh regarding Maritime English learning management. Due to the many hours of learning in Maritime English the cadets at BP2IP Malahayati Aceh rarely gets achievements seen from various English language competitions between campuses in regions or nationally rarely get the runner up.

The results of the study show that: (1) Planning for learning maritime English in BP2IP Malahayati consists of compiling syllabus in accordance with IMO Model Course 3.12 and compiling lesson plan (RPP) at the beginning of the semester; (2) The implementation of Maritime English learning at BP2IP Malahayati consists of initial activities, core activities delivered by learning materials and closing activities of the instructor giving assignments or quizzes to determine the extent to which students receive learning: (3) Evaluation of Maritime English Learning at BP2IP Malahayati carried out monitoring of students on 4 aspects, namely Listening, reading, speaking and writing. For the mid semester, midterms are given and at the end of the semester are given final semester examinations and practical exams.

\section{- THEORETICAL FRAMEWORK Learning Management}

Management contains the basis of philosophy and elements that have similarities, namely management has goals to be achieved, where those goals have been set in advance; achievement of objectives is carried out through delegation of authority to employees and the achievement of the organization carried out through the functions of planning, organizing, directing, leadership and supervision so that the use of "human" and "non human" factors can be carriedout effectively and efficiently(Johannessen, 
2020; Vanharanta, \& Markopoulos, 2019; Ji, 2018). Management is science and art in regulating, controlling, communicating and utilizing all existing resources in the organization by utilizing management functions (Planning, Organizing, Actuating, Controlling) so that the organization can achieve its objectives effectively and efficient.

Can be seen from the broad and narrow meaning that Management in the broadest sense is planning, implementing and monitoring $(\mathrm{P} 3)$ organizational resources to achieve goals effectively and efficiently. Management in the narrow sense is school management which includes: school program planning, supervisor/ evaluation and school information system (Capel, Leask, \& Younie, 2019; Redfern, 2019; Beare, Caldwell, \& Millikan, 2018; Ndhlovu, 2018; Zepeda, 2016).

Efforts to find the best way to achieve higher quality, relevant, effective and efficient education goals require a decentralized approach to education management that delegates greater decision-making at the lower management level ie schools.

Other opinion states that management is an activity to achieve predetermined goals or objectives by utilizing other people's sources (getting things done through the effort of other people) Haila, 2020; Mihova, NikolovaAlexieva, \& Angelova, 2018). From this understanding, it implies that there are five elements of management, namely: leaders, people (executors) who are led, goals to be achieved, cooperation in achieving these goals and facilities or management tools (tools of management).

The opinion above can be concluded, management is a science to regulate, control, communicate and utilize resources within the organization to achieve certain goals effectively and efficiently that have been determined by utilizing management functions namely planning, organizing, moving/actuating, and controlling.
Broadly speaking, quality learning management/quality oriented to customer satisfaction is the goal of the organization, the customer is placed as king. King is the Subject the must be the center of all ideal, satisfying services (Aquilani et.al., 2017; Lussier \& Hendon, 2017; Jaber, 2016). Customers should not be dispointed because they have the strength, buy independetly, customers must get privileges like a king because they have desires that must be agreed upon. In addition to an absolute understanding, quality can also interpreted as relative, namely about understanding of quality from perspective of accuracy with the original goal of meeting customer needs and desires.

\section{English learning}

Learning shows in an activity towards a change of behavior in the individual through the process of interaction with the environment (Jalal \& Mahmood, 2019; Mihova, NikolovaAlexieva, \& Angelova, 2018; Braghirolli et.al., 2016). Learning is a transactional communication process in which there is a reciprocal nature between students and students with other learning resources in a particular learning environment to achieve certain goals.

A powerful and effective learning process is not a stand-alone activity, but is related to a variety of interrelated factors. In KBBI (Indonesian Dictionary) Learning is a process, method, action to make people or living things learn (Narushima, Liu, \& Diestelkamp, 2018; Lake, 2017). Learning is the process of interaction of students with educators and learning resources in a learning environment. Learning is assistance provided by educators so that the process of acquiring knowledge and knowledge can occur, mastery of proficiency and character, and the formation of attitudes and beliefs in students. In other words, learning is a process to help students learn well. 
Study and learning have a connection. Learning is an individual process of doing something that results in changes in attitudes, thought patterns, behavior, and good thoughts that can occur in the lives of individuals both there and the absence of other people who deliberately interfere in the learning process (Boylan et.al., 2018; Çam, \& Geban, 2017; Girardi, 2016).

Based on the opinion above it can be concluded, learning is a systematic process through the stages of the learning approach, namely planning, implementation and assessment. Learning is carried out in the presence of learning strategies so that learning gets success and success in achieving goals.

Maritime English Subject is more specific than English in general. Because its reviewed about English that is used in maritime or English which is used when sailing on a boat. Based on the IMO Model Course 3.12 and the curriculum determined by the Ministry of Transportation (Kemenhub) oversees the Sea Transportation Human Resource Development Agency (BPSDMPL).

\section{METHODS}

The research used is qualitative research which in fact will be presented in descriptive analysis. This study aims to describe systematic or factual descriptions or paintings of facts, characteristics and correlation between phenomena related to the management of maritime English language learning at the Science and Education Training Center (BP2IP) Malahayati Aceh, then grouped, analyzed and concluded.

\section{RESULTS AND DISCUSSION}

In conducting research, researchers conduct interviews, direct observation and take documentation to determine management functions carried out. The discussion is in accordance with management functions which have three management elements, namely planning, implementation and evaluation. Interviews were carried out by interviewing principals, instructors and cadets, as follows:

\section{Planning Maritime English Learning at BP2IP Malahayati}

The Principal leads the Maritime English learning planning activities carried out by the instructor, monitors directly the planning of the plan and ensures that the learning planning is in accordance with the objectives of Maritime English learning written in the applicable curriculum. in the learning process. The difficulty in drafting is the lack of understanding of the sources of the curriculum and the IMO Model Course. Planning made by the instructor is to make the syllabus in accordance with the applicable curriculum and then make a plan for implementing learning (RPP). Planning is made before starting learning at the beginning of the semester.

Planning is a very important part of the learning process, and certainly determines the achievement of the learning objectives themselves. The need to prepare a Learning Plan or lesson plan has actually been realized by the teachers, but the problem is the level of care of the teachers to present good and systematic teaching, as well as their level of expertise in each scientific discipline that is not sufficient to be able to design a learning concept.

\section{Implementation of Maritime English Learning at BP2IP Malahayati}

The implementation of learning that has taken place is in accordance with the opinions of the experts above. Principals who play a role in the implementation of Maritime English learning, in this case there are many who do the principal, both overseeing directly and through the Chair 
of the Functional Position Group and can be assessed the results of performance, absenteeism and the success of educating them.

The implementation of Maritime English learning has been carried out in accordance with the planning which is listed in the learning implementation plan (RPP) that was made at the beginning of the semester. The implementation of learning has utilized the media provided by BP2IP Malahayati Aceh, both the laboratory and around the school. Maritime English learning methods are given according to the abilities of students. For the beginning of learning the teacher reviews the past learning first before continuing the material to be delivered at that time. Then proceed to fill out the learning materials and at the end of the teaching instructor give assignments or quizzes to find out the extent to which students receive learning at that time.

That in the implementation of learning in the classroom teachers use the steps in the 2013 Curriculum including preliminary, core and concluding activities. At the core activity, the teacher uses a scientific approach with the stages of observing, asking, reasoning, and communicating.

\section{Evaluation of Maritime English Learning at BP2IP Malahayati}

Evaluation of Maritime English learning in its implementation by the teacher performs a number of things, namely, at the end of each lesson monitoring will be carried out to students by means of special notes on 4 aspects, namely listening, reading, speaking and writting. And for the mid semester the midterm is given and at the end of the semester the final semester exams and practical exams are given. The other activities of the instructor do various things to develop the potential of students by holding extracurricular, co-curriculum and other interesting activities to increase motivation to learn especially in the field of Maritime English.
Teachers who succeed in learning are not only able to deliver material, use methods and media well, but also must be supported by evaluation activities. Because from the results of the evaluation it is known the ability of teachers and students in the learning process. At the time of formulating the assessment tool also must see the level of difficulty of the questions made by the teacher.

\section{CONCLUSIONS}

Some items related to Maritime English learning planning are compiling the syllabus in accordance with IMO Model Course 3.12, compiling a lesson plan for learning (RPP) at the beginning of the semester. The implementation of Maritime English learning consists of initial activities, core activities and closing activities. In accordance with the compiling lesson plan (RPP) that was made at the beginning of learning a review or review of the lessons that were taught the previous day was conducted. Then in the core activities, the learning materials are delivered and at the end of the learning process the teacher gives assignments or quizzes to find out the extent to which students receive learning. In the implementation of teaching learning is able to utilize the learning media that have been provided. Evaluating Maritime English learning instructors performs a number of things, namely, at the end of each lesson monitoring will be carried out to students by having specific notes on 4 aspects, namely listening, reading, speaking and writing. And for the mid semester the midterm is given a test and at the end of the semester a final semester examination and a practical examination are given. Activities are carried out in various ways to develop the potential of students, namely holding extra-curricular, co-curriculum and other interesting activities to increase learning motivation, especially in the field of Maritime English.

Head of BP2IP Malahayati Aceh must 
immediately make a discussion program for instructors of Maritime English and instructors from the field of marine affairs so that the delivery of Maritime English is in accordance with maritime science. Teachers of Maritime English in implementing learning must have mastered the material to be delivered in accordance with the IMO course model 3.12. Teachers must have a strategy for each implementation of learning so that students have a great interest in each lesson. Making learning interesting and eager to be followed.

\section{- REFERENCES}

Aquilani, B., Silvestri, C., Ruggieri, A., \& Gatti, C. (2017). A systematic literature review on total quality management critical success factors and the identification of new avenues of research. The TQM Journal.

Beare, H., Caldwell, B. J., \& Millikan, R. H. (2018). Creating an excellent school: Some new management techniques. Routledge.

Boylan, M., Coldwell, M., Maxwell, B., \& Jordan, J. (2018). Rethinking models of professional learning as tools: a conceptual analysis to inform research and practice. Professional development in education, 44(1), 120-139.

Braghirolli, L. F., Ribeiro, J. L. D., Weise, A. D., \& Pizzolato, M. (2016). Benefits of educational games as an introductory activity in industrial engineering education. Computers in Human Behavior, 58, 315-324.

Çam, A., \& Geban, Ö. (2017). Effectiveness of case-based learning instruction on preservice teachers' chemistry motivation and attitudes toward chemistry. Research in Science \& Technological Education, 35(1), 74-87.

Capel, S., Leask, M., \& Younie, S. (Eds.). (2019). Learning to teach in the secondary school: A companion to school experience. Routledge.

Girardi, G. (2016). Changes in Attitude Towards Climate Change and Transformative Learning Theory. In Implementing Climate Change Adaptation in Cities and Communities (pp. 321-352). Springer, Cham.

Haila, A. A. (2020). Educational management in modern conditions. In World economy and international economic relations (Vol. 3, pp. 71-75).

Jaber, M. Y. (2016). Learning curves: Theory, models, and applications. CRC Press.

Jalal, A., \& Mahmood, M. (2019). Students' behavior mining in e-learning environment using cognitive processes with information technologies. Education and Information Technologies, 24(5), 2797-2821.

Ji, S. (2018, December). Enlightenment of Taoist Management Philosophy to Modern Enterprise Management. In Third International Conference on Economic and Business Management (FEBM 2018). Atlantis Press.

Johannessen, J. A. (2020). Knowledge Management Philosophy: Communication as a Strategic Asset in Knowledge Management. Emerald Group Publishing.

Lake, B. M., Ullman, T. D., Tenenbaum, J. B., \& Gershman, S. J. (2017). Building machines that learn and think like people. Behavioral and brain sciences, 40.

Lussier, R. N., \& Hendon, J. R. (2017). Human resource management: Functions, applications, and skill development. Sage publications.

Mihova, T., Nikolova-Alexieva, V., \& Angelova, M. (2018, June). Factors affecting Business Process Management in the Bulgarian enterprises to achieve sustainable 
586 | Jurnal Pendidikan Progresif, Vol. 11, No. 3, pp. 580-586, December 2021

development. In 2018 International Conference on High Technology for Sustainable Development (HiTech) (pp. 1-5). IEEE.

Narushima, M., Liu, J., \& Diestelkamp, N. (2018). I learn, therefore I am: A phenomenological analysis of meanings of lifelong learning for vulnerable older adults. The gerontologist, 58(4), 696-705.

Ndhlovu, L. N. (2018). Investigating the effectiveness of a community based approach towards solid waste management in Windhoek's Okahandja Park (Doctoral dissertation, University of Namibia).

Redfern, G. B. (2019). Evaluating teachers and administrators: A performance objectives approach. Routledge.

Vanharanta, H., \& Markopoulos, E. (2019). The applied philosophy concept for management and leadership objects through the Company Democracy Model. Theoretical Issues in Ergonomics Science, 20(2), 178-195.

Zepeda, S. J. (2016). Instructional supervision: Applying tools and concepts. Taylor \& Francis. 